\title{
IMPACT OF INTERNATIONAL TREATIES AND CONVENTIONS ON THE BRAZILIANARBITRATION LAW
}

Jamile Bergamaschine Mata Diz

Professor, Faculty of Law, UFMG. Professor at the University of Itauna-MG. PhD in Community Law from the Universidad de Alcalá, Spain. Master in Instituciones y Políticas de la UE from UCJC-Madrid. Legal Adviser of the Secretariat of Mercosur (2008-2009). E-mail: jmatadiz@yahoo.com.br.

Clarissa Correa Neto Ribeiro

Student at State Sciences, Faculty of Law, UFMG. Scholarship program PIBIC, CNPq. Academic mobility at the Université Lille 2. E-mail: clarissacnribeiro@gmail.com

\begin{abstract}
The arbitration as an alternative dispute settlement established itself nationally and internationally as a legitimate instrument to promote and expand access to justice. In this sense, the aim of this work is to analyze how the international treaties and conventions influenced the creation and development of the national arbitration law and its application in Brazil. Thus, we will seek to delimit what were the conventions, treaties, protocols and other international acts that had implications, positive or negative, when the adoption of Law n. 9307/96 by the Brazilian legislature, thereby seeking to analyze whether this law could actually absorb the parameters, criteria, nature and effects allowed by the international legal order. The correlation is also relevant to explain how Brazil has followed the international dynamics on bound rules to legal relations. Later, there will be an approximation, succinctly, on the main aspects of the law in relation to the object, subject, form of expression and effects of the use of arbitration and its respective application in Brazil.
\end{abstract}

Keywords: Impacts - International regulation - Brazilian legal system - arbitration.

\section{INTRODUCTION}

The arbitration as a dispute settlement consolidated its application both in the national and international levels. The discussion and subsequent acceptance of new methods to resolve conflicts has 
reached a significant degree of normativity as international conventions and treaties on the subject were created, as well as domestic laws conducive to the establishment of the means of arbitration.

In this sense, the study of the influence and impact of international law on the national system deserves special attention by the doctrine, in order to establish which measures, the effects and scope of the international provisions that had major repercussions on the creation of Brazil's own specific law that focuses on the issue of arbitration. Therefore, the aim, of the present work is to try to define what were the conventions, treaties, protocols and other international acts that had implications, positive or negative, when the adoption of Law n. 9307/96 by the Brazilian legislature, seeking to analyze whether this law could actually absorb the parameters, criteria, nature and effects allowed by the international legal order. The correlation is also relevant to explain how Brazil has followed the dynamics on the international standards related to legal relations.

In this paper, we will analyze the main treaties and conventions in the field of arbitration, especially those that were incorporated in Brazil, so we can devote ourselves to the object of the research concerning the impacts and implications of these acts of international character on the formulation of the national arbitration law. Later, there will be an approach, briefly, on the main aspects of the law in relation to the object, subject, form of expression and effects of the use of arbitration and its respective arbitration in Brazil.

The methodology of the present work shall be centered on established techniques for an interdisciplinary research involving issues of international law and its treatment and incorporation by internal system, especially because of the specific and unique character examination of an extra-judicial mechanism and therefore not necessarily bound to a direct state activity. In this sense, there shall be used methods that allows analyzing the construction of international normativity concerning arbitration and its adoption by the Brazilian order. The historical and inductive methods will establish the conceptual assumptions and practices applicable to the use of this innovative mechanism as concretizing the fundamental right of access to justice within the legal relations of a private nature.

For a proper understanding of the subject, the present paper will begin with the definition of a theoretical framework that allows specifying a concept for arbitration, but without disregarding the existence of understandings or differing opinions on this definition. 
The legal institution of arbitration is one of the oldest forms of conflict resolution in the history of law. Existing since the dawn of civilizations, it has records on Greeks reports, Romans and even biblical or mythological, where to a third party was delegated the responsibility to resolve controversies over the existence of rights, executing justice privately. Although the Commercial Code of 1850 represents the first legal instrument to address arbitration in Brazil, by providing, in Article 245 , that conflicts arising from commercial leases should be decided in arbitration, there are records of its use yet by the times of Portuguese colonial domination. Later, the contents of the article were incorporated to the Civil Code and the issue of arbitration was included in various legal devices, which either encompassed it or restricted it during the course of political history.

Arbitration or arbitral judgment can be defined as an extrajudicial form of dispute resolution, whereby arbitrators resolve divergences concerning available property rights, based on the arbitration agreement covenanted between the parties. Still, according TEIXEIRA' it is " $(. .$. a non-statal form of controversy composition, as it develops 'under the State's auspices and guarantees, but with the decision delegated to a particular, whose decisions are stabilized once uttered, including with typical sanctions of a state solution. "

The understanding of CASELLA and ARAÚJO states that ${ }^{2}$

Arbitration is a legal mean of dispute resolution, present or future ones, based on the will of the parties involved, which elect themselves and directly, or through certain mechanisms determined by them, arbitrators to be judges of the disputes, trusting them the mission to mandatorily decide the

\footnotetext{
1 “(..) uma forma paraestatal de composição de controvérsias, pois se desenvolve 'sob os auspícios e garantia do Estado, mas com a decisão delegada a particular, cujas decisões se estabilizam uma vez proferidas, inclusive com sanções típicas de solução estatal." TEIXEIRA, Sálvio de Figueiredo apud FIGUEIRA JR., Joel Dias. Arbitragem, Jurisdição e Execução: Análise crítica da Lei 9.307, de 23.09.1996. $2^{a}$ ed. São Paulo: Revista dos Tribunais, 1999, p. 123 (our tanslation).

2 “A arbitragem é um meio jurídico de solução de controvérsias presentes ou futuras, baseado na vontade das partes envolvidas, as quais elegem por si mesmas e diretamente, ou através de mecanismos por elas determinados, árbitros para serem os juízes as controvérsias, confiandolhes a missão de decidir de forma obrigatória o litígio através da prolação de um laudo arbitral. Ao final da arbitragem, idealmente, espera-se que o laudo seja cumprido espontaneamente. Sua natureza em nada se modifica em virtude de ser as arbitragem interna ou internacional." BORBA CASELLA, Paulo e ARAÚJO, Nádia de. Arbitragem: a nova lei e a praxe internacional. Borba Casella, P. (coord.). São Paulo: LTr, 1999, p. 90 (our translation).
} 
dispute through the delivery of an arbitral award. At the end of the arbitration, ideally, it is expected that the award is accomplished. Nothing in its nature is modified by virtue of being a domestic or international arbitration.

When entering the subject of the legal nature of arbitration, soon it is possible to find out that the doctrine remains divided into two antagonistic trends: a contract theory (or private) and the theory tribunal (or publicist, or even institutional).

The contractual characteristic of arbitration arises from the arbitration agreement between the parties. For the followers of the private tradition, "the enforcement of the award, which must be made by the judiciary, constitute mere obligation, assumed the arbitration agreement"3. However, recognizing the State, the judicial nature of arbitration, "the predominant act of the institute is the award, the result of a public activity delegated to the arbitrator"4.

There are still those who try to reconcile the two trends, printing a sui generis nature to the institute. The idea is based on that the arbitration is born of the free will of the parties (privately), and yet, however, has a function of a public nature, as it regulates a procedural law relationship. To those who defend the mixed nature of arbitration, besides the contractual nature, the institution has also has feature public as to this part of the doctrine, the effects of award would result from the law.

\section{INTERNATIONAL REGULATION ON ARBITRATION}

During the twentieth century, with the inclusion of the world into an international economic order and with the constant changes generated by a globalized capitalism, in a society where the speed and complexity of personal and economic relations are intensified, the need to enable mechanisms, adapted to this new reality, to solve legal disputes is created. In this way, arbitration is presented as a mean easily adaptable to this new enviroment, being celebrated in several international Conventions, such as the Geneva Protocol concerning Arbitration Clauses (1923), which recognized the validity of the arbitration clause as legally valid when arbitration is international, the

3 "a execução forçada do laudo, que deve ser efetuada pelo Judiciário, constituiria mera obrigação de fazer, assumida na convenção arbitral". SANTOS, Ricardo Soares Stersi dos. Mercosul e Arbitragem Internacional Comercial: aspectos gerais e algumas possibilidades. Belo Horizonte: Del Rey, 1997, p. 133 (our translation).

4 "o ato predominante do instituto é o laudo, resultado de uma atividade pública delegada ao árbitro". Ibidem. 
New York Convention on the Recognition and Enforcement of Foreign Arbitral Awards (1958), which came to replace the first, given its scope, since it was sponsored by the United Nations and has been ratified more than 100 countries; the European Convention on International Commercial Arbitration (1961) and the Convention of Panama (1975), that became regional instruments for the arbitration, the Washington Convention for the Settlement of Investment disputes between States and Nationals of Other States (1965) and the Model Law on Commercial Arbitration UNCITRAL (1985), which was prepared by the United Nations and became an important harmonizing instrument of international arbitration legislation.

Therefore, it is important to analyze the influence of Private International Law and its Treatises on the development and implementation of the Brazilian Arbitration Law, Law no. 9307 (September 23, 1996), from the perspective of Brazil's need for inclusion and adaptation to the international scene. Although this law does not inaugurate arbitration in the national legal plan, it is responsible for the most modern systematization of the subject and, thus, to understand the influences under which Brazilian jurisprudence was situated in relation to arbitration at the time of this law's elaboration, will reveal the mechanisms that provided the development of its application in the country, either by strengthening the reliability of Brazil for international trade, either by its alternative for the overloaded national court system.

When proceeding with the development of this analysis, we seek to define and examine the existing international treaties relating to arbitration that influenced Brazilian legislators, in order to demonstrate its role in the modernization of the model of the arbitration judge and to enable understanding the importance of adjusting to international parameters for the diffusion and adoption of this alternative method of dispute resolution.

Although it is necessary to emphasize that Brazil took its first step regarding international instruments on arbitration in 1932, with the accession and ratification of the Geneva Protocol of 24 September 1923, relating to arbitration clauses, until the enactment of Law 9307, the theme was neglected in this country.

From the 1980s and on, given the observed need to consolidate an effective alternative mechanism for conflict resolution, three law drafts on arbitration were presented in Brazil, in order to modify the treatment of this institute in Domestic Law, but they weren't successful. Thus, following the understanding of Delgado ${ }^{5}$

5 "A história recente registra que a Lei no 9.307, de 23 de setembro de 1996, teve origem no Projeto de Lei do Senado de $\mathrm{n}^{\circ} 78$, de 1992. Antes, três projetos tinham sido apresentados e foram arquivados. (...) O Projeto em referência foi apresentado pelo então Senador Marco Maciel. Contribuíram para o aperfeiçoamento do texto da Lei, valiosas sugestões, de juristas 
Recent history registers that the Law No. 9307 of September 23, 1996, was originated by the Senate's law draft No. 78, 1992. Before, three projects were presented and were filed. (...) The Project in reference was presented by Senator Marco Maciel. Contributed to the improvement of the text of the law, valuable suggestions of legal scholars, including Drs Carlos Alberto Carmona and Peter Martins Batista, as well as Dr. Selma M. Ferreira Lemes. The author of the project, in the explanatory memorandum, stated that the legislative proposal took into account the guidelines of the international community, especially those set by the UN Model Law on International Commercial Arbitration formulated by UNCITRAL.

As a United Nations agency responsible for the modernization and harmonization of the rules pertaining to international trade, UNCITRAL (United Nations Commission for International Trade Law) drafted, with a committee made up of 58 countries and 18 international organizations, the Model Law on arbitration above. Its final text was approved by the General Assembly of the United Nations on December 11,1985 , by resolution $40 / 72$ and the success of the legislation was notable for having the accession of the countries that currently handle the majority of international trade.

In addition to troubleshoot previous legislation's failures, the text of the Model Law has influenced most countries' internal laws on arbitration promulgated after its approval, as well as a review of arbitral rules in most arbitration chambers on the planet, because of the extent and relative completeness of its approach, which goes from formation to execution of sentences.

In addition, as understood Delgado ${ }^{6}$ referencing to Garcez, it is

estudiosos do tema, incluindo-se os Drs. Carlos Alberto Carmona e Pedro Batista Martins, bem como, a Dra. Selma M. Ferreira Lemes. O autor do projeto, na exposição de motivos, esclareceu que a proposta legislativa apresentada levava em conta diretrizes da comunidade internacional, especialmente as fixadas pela ONU na Lei-Modelo sobre Arbitragem Comercial Internacional formulada pela UNCITRAL". DELGADO, José Augusto. A Arbitragem no Brasil - Evolução histórica e conceitual. P. 7, our translation. Available at: http://www.escolamp.org. br/arquivos/22_05.pdf

6 "Um estudo levado a efeito pelo Professor Pieter Sanders (Professor emeritus na Universidade de Rotterdam, artigo constante do vol. II $n^{\circ} 1$ do Arbitration International, LCIA, 1995), registra que o impacto da Lei-Modelo é tão elevado que praticamente nenhum Estado que tenha modernizado seu sistema legislativo sobre arbitragem, após a sua edição, teria, inter alia, deixado de levá-la em consideração. Alguns Estados adotaram a Lei-Modelo por inteiro, 
possible to understand how the Model Law's influences spread through national laws:

A study carried out by Professor Pieter Sanders (professor emeritus at the University of Rotterdam, Article constant vol. II No. 1 Arbitration International, LCIA, 1995), notes that the impact of the Model Law is so high that virtually no State that has modernized its system of arbitration law, after its release, would, inter alia, have failed to take it into consideration. Some states have adopted the Model Law as a whole, others have adapted most of its provisions, so that there are countries that can be characterized as Model Law countries (...). Until 1995, when the study of Professor Pieter Sanders was conducted, 22 countries had enacted domestic laws on arbitration adapting them substantially to the standards of Model Law.

In order to understand Model Law's influences and the impacts on the Brazilian national legal system, we shall proceed to an analysis, article by article, of the national legislation to find out the compatibility between both legal instruments.

\subsection{Influences of International Law on the Formulation of National Arbitration Law}

Brazilian legislators also adhered to the importance of the Model Law, during the process that enacted the national law. According to Professor Selma Lemes' article, member of the jurists Commission who contributed to the drafting of the Law 9.307/96, it would be possible to establish a framework with the following overview of the Model Law influences on Brazilian law: law

Main provisions of the Model Law incorporated into domestic

outros se adaptaram a maior parte de suas provisões, de forma que existem países que podem ser caracterizados como países da Lei-Modelo (Model Law countries) (...). Até 1995, quando o estudo do Professor Pieter Sanders foi realizado, 22 países haviam promulgado leis internas sobre arbitragem adaptando-as, substancialmente, aos padrões da Lei-Modelo." Ibidem, p. 5, our translation. 
Panorama of Brazilian Law. Vol 1, No 1 (2013)

\begin{tabular}{|c|c|c|}
\hline Disposal & Model Law & $\begin{array}{c}\text { Brazilian } \\
\text { Arbitration } \\
\text { Law }\end{array}$ \\
\hline $\begin{array}{l}\text { Recognition of mandatory and binding } \\
\text { effect of the arbitration clause and its } \\
\text { enforceability; wide range of parts to fix } \\
\text { the procedural rules. }\end{array}$ & Article 8 & $\begin{array}{l}\text { Article } 3 \\
\text { to } 7\end{array}$ \\
\hline $\begin{array}{l}\text { Procedure for the nomination of } \\
\text { arbitrators. }\end{array}$ & Article 11 & Article 13 \\
\hline $\begin{array}{l}\text { Revelation of the referee prior to any } \\
\text { facts that denote justified doubts as to his } \\
\text { impartiality and independence }\end{array}$ & $\begin{array}{l}\text { Article } 12 \\
\text { and } 13\end{array}$ & $\begin{array}{l}\text { Article } 14, \\
\text { paragraph } 1\end{array}$ \\
\hline $\begin{array}{l}\text { Principles of autonomy of the clause } \\
\text { of commitment and Principle of } \\
\text { competence-competence }\end{array}$ & Article 15 & $\begin{array}{l}\text { Article } 8 \\
\text { and sole } \\
\text { paragraph }\end{array}$ \\
\hline $\begin{array}{l}\text { Authorization for the arbitral tribunal to } \\
\text { request precautionary measures }\end{array}$ & Article 17 & $\begin{array}{l}\text { Article } 22, \\
\text { paragraph } 2 \\
{ }^{\circ} \text { and } 4^{\circ}\end{array}$ \\
\hline Principle of due process & Article 18 & $\begin{array}{l}\text { Article 21, } \\
\text { Paragraph } 2\end{array}$ \\
\hline $\begin{array}{l}\text { Motivated decision: the arbitrators } \\
\text { shall base the decision rendered in the } \\
\text { arbitration award }\end{array}$ & Article 31 & $\begin{array}{l}\text { Article 26, } \\
\text { section III }\end{array}$ \\
\hline $\begin{array}{l}\text { Choice of law rules that apply in } \\
\text { arbitration }\end{array}$ & Article 28 & Article 2 \\
\hline $\begin{array}{l}\text { Recognition and enforcement of foreign } \\
\text { arbitral award }\end{array}$ & $\begin{array}{l}\text { Section } 35 \\
\text { and } 36\end{array}$ & $\begin{array}{l}\text { Article } 38 \\
\text { and } 39\end{array}$ \\
\hline $\begin{array}{l}\text { Revision procedure after award is planned } \\
\text { based on (i) rectification to correct } \\
\text { clerical error or clarify obscurities applied } \\
\text { to the tribunal and (ii) action for the } \\
\text { annulment of the arbitral award }\end{array}$ & $\begin{array}{l}\text { (I) Article } \\
33 \\
\text { (Ii) Article } \\
34\end{array}$ & $\begin{array}{l}\text { (I) Article } \\
30 \\
\text { (Ii) Article } \\
32 \text { and } 33\end{array}$ \\
\hline Source: own elaboration based on Lemes (1997). & & \\
\hline
\end{tabular}


The author also cites the influence of domestic laws of other countries in Brazilian law:

The Brazilian arbitration rules also had inspiration in the 1981 French law as it establishes the arbitration agreement, which has also a prevision in art. 7, Model Law, (art. 3 Brazilian law), as well as in many devices of the Spanish Law No. 36/1988, for example, art. 56.1, equivalent to art. 34 Brazilian Law ${ }^{7}$.

In lectures, the author also stated that, during the development of the Brazilian law, there was no estimation of when international conventions would be incorporated into the domestic legal system. From this point, it is possible to realize the wisdom of the legislator, which provides in Article 34 of this law that effective international treaties on domestic law would prevail upon the national law, highlighting the supplementary nature of the legal order for the items shown in the Chapter and anticipating the effects of future treaties' incorporation.

In fact, the committee rapporteur made extensive research in the international legal framework, and sought, beyond what had already been written, to incorporate important devices of widely accepted Conventions, in order to facilitate transactions and international legal traffic. Thus, there is also the influence of the New York Convention on the Recognition and Enforcement of Foreign Arbitral Awards, 1958, which can be noted as it extinguishes the need of a requirement of dual approval of sentences and it inserts the device of reversal of the burden of proof. Carlos Alberto Carmona also states on the influences that "it can be seen that in the six sections of art. 38 and art. 39 all cases of refusal of approval provided in art. V of the New York Convention were related." 8

During the drafting process of the Brazilian Arbitration Law, Brazil ratified some relevant conventional international acts dealing directly or indirectly the subject, namely:

- Protocol of Las Lenas ${ }^{9}$, signed on July 27, 1992: which proposes cooperation rules and Jurisdictional Assistance in Civil, Commercial,

7 LEMES, Selma. Princípios e origens da Lei de Arbitragem. REVISTA DO ADVOGADO Associaçao dos Advogados de Sao Paulo, n 51, outubro/1997. Pags 32 - 35.

8 "verifica-se que nos seis incisos do art. 38 e no art. 39 foram relacionados todos os casos de recusa de homologação previstos no art. V da convenção nova-iorquina." CARMONA, Carlos Alberto. Arbitragem e Processo - Comentários à lei 9.307/96. 2a ed. São Paulo: Atlas, 2004, p. 295 , our translation.

9 Incorporated by Decree n. 2067, of November 12, 1996. 
Labor and Administrative issues, in MERCOSUR. It indicates strategies for resolving conflicts between individuals or corporations.

- International Commercial Arbitration Agreement of MERCOSUR ${ }^{10}$, signed in 1998: Standardize implementation of the arbitration between the Parties, it has been prepared based on the UNCITRAL Model Law, and has as its object to "regulate private arbitration as an alternative dispute resolution for controversies arising from international commercial contracts between individuals or legal entities of private law "(art. 1), therefore being excluded the arbitration in disputes between an individual and a State Party and those arising between States, since in these cases the mechanism under the Protocol of Olivos should be triggered.

- Inter-American Convention on Commercial Arbitration ${ }^{11}$ signed in Panama on January 30, 1975: which was modeled after the New York Convention, 1958, and provides to the signatories countries the general enforceability of arbitration agreements and arbitral awards.

- Inter-American Convention on Extraterritorial Validity of Foreign Judgments and Arbitral Awards ${ }^{12}$, signed in Montevideo on May 8, 1979: that regulates the enforcement of judgments and arbitral awards in other member states of the OAS.

All these Conventions affected, in a greater or lesser extent, the development and subsequent application of national law, but, among those cited, it should be said that the Panama Convention, was the main source of inspiration to the Brazilian legislator, as it brings very similar provisions to contained in the New York Convention, although we must emphasize that the first one has a smaller scope, since the latter has been adopted by over 130 countries, including Brazil, albeit belatedly. Even though the New York Convention can be considered a legal source of inspiration, it was only adopted in the domestic sphere in 2002, through Decree No. 4,311.

From this brief analysis, we can see the influence of the International Law Conventions on Arbitration in the composition of the national law. Even before the incorporation of some normative instruments to the domestic legal system, certain guarantees were necessary to the national legislation so that the country could have a higher reliability at an international level as far as it is concerned on legal protection of arbitration issues.

It is also worth mentioning, however, that even if the Brazilian Arbitration Law bring in your text exactly the same provisions contained in other international conventions, this would not be sufficient to create

10 Incorporated by Decree n. 4719, to June 4, 2003.

11 Incorporated by Decree n. 1,902, of May 9, 1996.

12 Incorporated by Decree No. 2,411, of December 2, 1997 
a trust in the legal protection for the community international, as a rule, the content of the internal laws of the countries are not known, internationally. Therefore, we understand the importance of both the consonance of domestic legislation with international acts applied, and adherence to international treaties National widely adopted.

Now, the question of legal certainty should also be analyzed from the perspective of the application and subsequent interpretation of recognition and admissibility of the effects of the report on legal relations. Even if there is a specific regulation mechanism regarding the use of arbitration, this only gains momentum as the judicial authorities are inclined by the due observance of the will of the parties to submit to this form of dispute resolution, and manage to admit that under private sphere, individuals can condone the way that best suits them, subject to the limits laid down by the system, as discussed earlier. The adoption of a law according to the most advanced international standards do not have the power to provide the necessary legal certainty if the Brazilian institutions fail to understand the importance of the institute even for achieving the fundamental right of access to justice.

Therefore, in order to help understand how the subject has been treated in Brazil, we shall now proceed to an analysis of the national arbitration legal framework and its application.

\section{GENERAL ASPECTS OF ARBITRATION LAW AND ITS APPLICATION IN BRAZIL: OBJECT, SUBJECT, FORM OF EXPRESSION AND EXECUTION}

Law of arbitration in Brazil was born of efforts by the Liberal Institute of Pernambuco, which brought together representatives of professional associations and lawyers, and introduced a bill that would allow the use of arbitration mechanisms in Brazil ${ }^{13}$. The influence of international regulation is felt not only at the time of preparation and discussion of the bill, but also thereafter, when the effects of the implementation of the report on the national legal system, since by signing the Convention of New York, "Brazil has consolidated arbitration in international forums, providing even the recognition of international arbitral awards." 14

13 CARMONA, Carlos Alberto. Arbitragem e Processo - Comentários à lei 9.307/96. 2a ed. São Paulo: Atlas, 2004

14 "o Brasil consolidou a via arbitral em sede internacional, propiciando, inclusive, o reconhecimento das sentenças arbitrais internacionais.” GAIO JR., Antonio Pereira. Lei n. 9.307/96 : natureza, historicidade e constitucionalidade da arbitragem no Brasil. In: Arbitragem. GAIO JR., Antonio Pereira e MAGALHAES, Rodrigo Almeida. (coords). Belo Horizonte: Del Rey, 2012, p. 13, our translation. 
Generally, all matters dealing with available rights, of patrimonial character, which can be transacted, except disputes affecting public order, may be submitted to arbitration in Brazil.

The inalienable rights, such as issues relating to the status and capacity of persons, or those relating to family subjects, should be protected by the state jurisdiction. Likewise to be resolved, are the contentions that involve things that are forbidden or out of the trade; and those arising from natural obligations and criminal matters. Processes, whose solution is through voluntary jurisdiction, also claim to judicial intervention, "so that it ensures and grants the legality to the fact situation that, by mutual agreement, the parties have reached." 15

In labor matters, there is in principle, the possibility of adopting arbitration for collective bargaining, as it allows the use of other alternative forms as conciliation, following the provisions of art. 114 of the Brazilian Constitution, which understanding confirmed by the Superior Labor Court on different occasions ${ }^{16}$.

As for the person's ability to hire the 'derogation of state justice', Brazilian law establishes that the applicable law shall be the one from the country in which the individual is domiciled (LICC, art. $7^{\circ}$ ). This is a priori the analysis to be made when the setting of the arbitration agreement.

"The arbitration judgment conceived as a result of a free agreement between the parties, only becomes permissible between people who enjoy the legal autonomy to govern their legal relationship"17

15 PUCCI, Adriana Noemi. Arbitragem Comercial nos países do Mercosul. São Paulo: LTr, 1997, p.46.

16 Vide Agravo de Instrumento em Recurso de Revista n TST-AIRR-1475/2000-193-05-00.7, onde o Tribunal afirmou que « Na hipótese, o art. $5^{\circ}, \mathrm{XXXV}$, da Constituição Federal dispõe sobre a garantia constitucional da universalidade da jurisdição, a qual, por definir que nenhuma lesão ou ameaça a direito pode ser excluída da apreciação do Poder Judiciário, não se incompatibiliza com o compromisso arbitral e os efeitos de coisa julgada de que trata a Lei ${ }^{\circ}$ 9.307/96. É que nos termos do art. $9^{\circ}$ da mencionada lei, o compromisso arbitral é a convenção através da qual as partes submetem um litígio à arbitragem de uma ou mais pessoas; Portanto, a arbitragem caracteriza-se como forma alternativa de prevenção ou solução de conflitos à qual as partes aderem, por força de suas próprias vontades. As partes, por conseguinte, têm a faculdade de renunciar ao seu direito de recorrer à Justiça ou de exercer o seu direito de ação, visto que o inciso XXXV do art. $5^{\circ}$ da Constituição Federal não impõe o direito à ação como um dever, no sentido de que todo e qualquer litígio deve ser submetido ao Poder Judiciário. Dessa forma, as partes, ao adotarem a arbitragem, tão-só por isso, não praticam ato de lesão ou ameaça a direito. Assim, reconhecido pela Corte Regional que a sentença arbitral foi proferida nos termos da lei e que não há vício na decisão proferida pelo juízo arbitral, não se há de falar em afronta ao mencionado dispositivo constitucional ou em inconstitucionalidade da Lei $\mathrm{n}^{\circ}$ 9.307/96. »

17 "O juízo arbitral concebido como fruto da livre convenção entre as partes, só se torna admissível entre as pessoas que gozem da autonomia jurídica para disciplinar as suas relações 
and should the subject, hold still, the power of disposal over the object of the contract. It can be said that only people who can compromise, may submit a dispute to arbitration.

The legal entities of private law may compromise since their legal representatives, agents and prosecutors are duly authorized through special powers.

As to whether people of public law to submit to arbitration awards, it is necessary to highlight "the issue of immunities from jurisdiction and execution, under which it is customary in an international level, that sovereign states are not subjected to jurisdiction of another State, and do not accept being executed because of proceedings pursued in another, unless the State itself to accept voluntarily submission to foreign jurisdiction." 18

Thus, the state, by contracting with individuals or with another sovereign state, hardly accept to submit to the laws or courts of another country, presenting the concept of arbitration, as the most viable for both parties, as it allows the preservation of neutrality in the procedure.

In Brazil, in contracts of eminently public feature, the public interest must prevail over the particular.

Regarding the public-law legal person (Union, States, Municipalities and autarchies), they are excluded from the legal possibility of solving internal conflicts through arbitration in face of unavailability of Treasury properties, whence the public interest is intrinsic to the deal itself. Nonetheless, the principle is not absolute, because the exception can find legal prediction, with internal requirement (eg laws, decrees bidding documents with clause, etc $(. . .)^{19}$

jurídicas" THEODORO JÚNIOR, Humberto. Curso de Direito Processual Civil - volume I. Rio de Janeiro: Forense, 2005, p.316, our translation.

18 "a problemática das imunidades de jurisdição e de execução, em virtude das quais é costume, em nível internacional, que os Estados soberanos não se submetam à jurisdição de um outro Estado, e tampouco aceitem ser executados em razão de processos tramitados em um outro, salvo se o próprio Estado aceitar, voluntariamente, a submissão à jurisdição estrangeira" PUCCI, Adriana Noemi, op. cit., p. 51-52, our translation.

19 No que tange às pessoas de direito público interno (União. Estados, Municípios e Autarquias), estão excluídas da possibilidade jurídica de solucionar conflitos internos através da arbitragem, em face da indisponibilidade dos bens da Fazenda Pública, donde decorre o interesse público que é ínsito à própria lide. Nada obstante, o princípio não é absoluto, porquanto a exceção pode encontrar previsão normativa lato sensu, com requisito interno (v.g. leis, decretos editais de licitação com cláusula compromissória, etc.) FIGUEIRA JR., Joel Dias. Arbitragem, Jurisdição e Execução: Análise crítica da Lei 9.307, de 23.09.1996. 2a ed. São Paulo: Revista dos Tribunais, 1999, p. 176, our transalation. 
So the question encircles much more to know which subjects may be the object of an arbitration award, than to know who will appear as part of, so that in international contracts signed by state bodies there should be an express provision authorizing arbitration.

In relation to the form of expression of the will of the parties to submit to arbitration a solution, generally, this can occur in the inclusion of an arbitration clause, considered as a device inserted in the contract, or standalone instrument that you mention, just prior to the installation of the suit ${ }^{20}$, in which the parties claim to the arbitration judge, the discussion about the existence, validity and effectiveness of the made Convention. Or also, through arbitration commitment, made subsequently to the emergence of conflict, ie, after verification of the divergence of interests on a particular property, the parties may, by means of arbitration commitment, choose to arbitrate as a competent mechanism to its resolution ${ }^{21}$.

The Brazilian Arbitration Law equaled the two species, assigning them the generic name of the arbitration agreement. Thus, according to Freitas Camera "The law of arbitration creates a generic figure of the arbitration agreement, the private legal act whose purpose is the establishment of arbitration." 22

It is noteworthy that the principle of autonomy of the arbitration clause, inserted in the Brazilian Arbitration Law was formulated from the laws of countries such as Italy, Germany, Belgium, France, Spain and also UNCITRAL Model Law. This postulate is a corollary of the principle Kompetenz-Kompetenz, originated in German jurisprudential construction, whereby the referees have the ability to judge their own competence. Thus, in the words of Silva Oliveira ${ }^{23}$, discussing the

20 The insertion of the clause can be made at the time of contract formation, or also after its completion through standalone instrument.

21 VALLADARES, L. C. P., DIZ, J. B. M. Considerações sobre o Acordo de Arbitragem do MERCOSUL e a Lei de Arbitragem brasileira. Revista Parlatorium. FAMINAS: Belo Horizonte, v. 5, p.13 - 40, 2010

22 "A lei da arbitragem cria a figura genérica da convenção de arbitragem, ato jurídico privado cujo o efeito é a instauração da arbitragem."CÂMARA, Alexandre Freitas. Arbitragem - Lei 9.307/96. $4^{\mathrm{a}}$ ed. Rio de Janeiro: Lúmen júris, 2005, p. 2, our translation.

23 "Costuma-se tributar à Corte Suprema da antiga Alemanha Ocidental, em decisão proferida em 4.5.1955, a formulação da regra Kompetenz-Kompetenz, da mesma maneira que se costuma citar a Convenção de Nova Iorque sobre o Reconhecimento e a Execução de Sentenças Arbitrais Estrangeiras, de 10.6.1958, como fruto de inspiração de tal regra. No entanto, é nas disposições das Regras sobre Arbitragem da UNCITRAL, de 1976, e da Lei-Modelo sobre Arbitragem Comercial Internacional da UNCITRAL, de 1985, que se verifica a asserção mais contemporânea daquilo que por uns é chamado de princípio e, por outros, de regra, ou seja, quando o meio de solução de controvérsias é a arbitragem, compete ao árbitro ou à corte arbitral definir sua própria competência. Essa assertiva, recorrente no âmbito da arbitragem internacional, foi expressamente adotada pela Lei $\mathrm{n}^{\circ}$ 9.307, de 23.9.1996, também chamada 
above mentioned principle:

It is often attributed to the Supreme Court of the former West Germany, in a decision issued on 04.05.1955, the wording of the rule-Kompetenz Kompetenz, the same way they usually cite the New York Convention on the Recognition and Enforcement of Foreign Arbitral Awards, of 10.06.1958, as a result of inspiration from such a rule. However, it is the provisions of the UNCITRAL Arbitration Rules, 1976 and the Model Law on International Commercial Arbitration UNCITRAL, 1985, that there is a more contemporary statement of what is called by some as principle, and by others as a rule, indeed, when the means of dispute resolution is arbitration, the arbitrator or the court shall define its own jurisdiction. This assertion, appellant in international arbitration, was expressly adopted by Law No. 9307 of 23.9.1996, also called Marco Maciel Law or Law of Arbitration in its Articles 8, paragraph, and 20, caput.

Regarding the recognition and enforcement of the final report, they equate to a sentence, having thus the same effects executives that the latter has. Therefore, the winning party may have appeal to the judiciary for the magistrate to execute the award, if the required party does not voluntarily comply the arbitration award.

In Brazil, the Arbitration Act overcame the called 'double approval', which required prior approval in the country of origin and after, the report would be approved before the Supreme Court, obtaining the exequatur. After that, the competent judge could run it. The art. 35 of the Arbitration Law provides that "to be recognized or enforced in Brazil, a foreign arbitral award is subject only to the approval of the Supreme Court."

Nevertheless, an interesting question worthy of note concerns the application of the Protocol on Cooperation and Jurisdictional Assistance in Civil, Commercial, Labor and Administrative executed on Las Lenas that in art. 20, states that the judgments and arbitral awards rendered in the jurisdictions of the States Parties of MERCOSUR possess extraterritorial validity, as well, regardless of subsequent approval. However, this understanding is not peaceful. Thus, there

Lei Marco Maciel ou Lei de Arbitragem, em seus artigos $8^{\circ}$, parágrafo único, e 20, caput.” OLIVEIRA, Henrique Silva. Considerações sobre o princípio Kompetenz-Kompetenz na lei de arbitragem. Trigueiro Fontes Advogados, Curitiba, junho de 2005. 
are those who defend the extraterritorial effect to the decisions of the signatories of this agreement, for which, if this were not the correct understanding, there would be no justification for the Protocol ${ }^{24}$. Others believe that the major novelty of Protocol Las Lenas, was to authorize the recognition and enforcement of foreign judgments and awards through Letters Rogatory, through the Central Authority, constituting only as a facilitator.

There is even a judgment of the Supreme Court where the highest organ of the Brazilian Judiciary held a restrictive interpretation on the application of the Protocol of Las Lenas, expressing the belief that the exequatur given to for enforceability of letters rogatory could not be accomplished without submitting to the examination the President of the Court. The Supreme Court ruled in Special Appeal no. 7618/97 that it was harmful to Brazilian sovereignty and violated the text of the Basic Law of the Republic, to have any permission, requested by a letter rogatory issued by the judicial organ of another country, intended to permit in the country, the investigation, by foreign magistrates, of witness domiciled in Brazil, especially when it meant that the hearing - that should be done by the Brazilian federal judge - was held on a diplomatic mission maintained by the State that issued the letter to the Government of Brazil.

\section{CONCLUSION}

One cannot deny that arbitration represents an innovation for the legal settlement of disputes. The formation of an extrajudicial procedure establishing parameters to resolve a conflict is, by itself, an important element in the setting of legal relations, especially those linked to the private sphere. It is undeniable that as well CAPPELLETTI expresses this movement of alternative forms of dispute resolution:

"representa la búsqueda de instrumentos alternativos para la solución de los conflictos llevados a efecto fuera de las arenas judiciales, a través de sistema informal, no contencioso, donde se busca el consenso o cualquier forma amistosa que vincule las partes, amenizando los espíritus más belicosos $y$ reduciendo, así, los argumentos plantados por emulación; el resultado, consecuentemente, es bien más aceptado para el no vencedor." 25

24 MAGALHÃES, J. C. de. O Protocolo de Las Leñas e a eficácia extraterritorial das sentenças e laudos arbitrais proferidos nos países do Mercosul. Revista de Informação Legislativa Senado Federal, ano 36, n. 144, Brasília, out/dez 1999, p. 281-287

25 CAPPELLETTI, Mauro e GARTH, Bryant. El acceso a la justicia: la tendencia en el 
There is no doubt that the judicial system now faces a major crisis that hinders and weakens the access to justice, pillar of one of the most important fundamental human rights. Establishing a procedure more suited to the international legal practice, Brazil is "tuned" to the needs of individuals and companies, creating greater opportunity for investment and business by enabling people to, per se, establish the mechanisms to be used in case of conflicts.

Brazil, after the enactment of Law 9307 of 1996, also accompanied the dynamic creation of international mechanisms to resolve disputes and to establish arbitration as a legitimate mean of conflicts' composition and it has also provided for the adoption, in the midst of that law, of essential elements so that referred mechanism could be applied in legal relationships between individuals. These aspects were, to a greater or lesser extent, a result of internationally recognized instruments like the case of those adopted under the UNCITRAL, according the discussion above.

In addition, the Brazilian law in providing for arbitration as a proper mean for dispute settlement, set important parameters that, no doubt, and despite possible improvements to be made to the latter, printed more legal certainty, generating the degree of confidence necessary for individuals and companies who want to adopt the arbitration in legal relationships held by them. It also represents a unique opportunity for the disputes arising under private to develop with a degree of autonomy, subjected, of course, to the limits laid down in the legal system itself.

Finally, the possibility of using arbitration by private means opening the system to eminently private relations, ensuring the full realization of one of the fundamental pillars of a democratic state, namely, the existence of mechanisms for dispute settlement as part essential to the broader principle of access to justice.

\section{REFERENCES}

BORBA CASELLA, Paulo e ARAÚJO, Nádia de. Arbitragem: a nova lei e a praxe internacional . Borba Casella, P. (coord.). São Paulo: LTr, 1999. BORBA CASELLA, Paulo. Procedimentos da arbitragem: a nova lei brasileira, praxe internacional ea integração no MERCOSUL. Revista do Tribunal Federal da $1^{\text {a }}$ Região, Brasília, v. 9, n. 1, p. 129-148, jan./mar. 1997.

CÂMARA, Alexandre Freitas. Arbitragem - Lei 9.307/96. 4th ed. Rio de Janeiro: Lúmen júris, 2005.

CAPPELLETTI, Mauro e GARTH, Bryant. El acceso a la justicia: la tendencia en el movimiento mundial para hacer efectivos los derechos.

movimiento mundial para hacer efectivos los derechos. México: Fondo de Cultura Económica, 1996. 
México: Fondo de Cultura Económica, 1996.

CARMONA, Carlos Alberto. Arbitragem e Processo - Comentários à lei 9.307/96. 2nd ed. São Paulo: Atlas, 2004.

DELGADO, José Augusto. A ARBITRAGEM: direito processual da cidadania. Available at: http://egov.ufsc.br/portal/sites/default/files/ anexos/29760-29776-1-PB.pdf, Access on 24/10/2012

A Arbitragem no Brasil - Evolução histórica

e conceitual. Available at: http://www.escolamp.org.br/arquivos/22_05. pdf Access on 24/10/2012.

FIGUEIRA JR., Joel Dias. Arbitragem, Jurisdição e Execução: Análise crítica da Lei 9.307, de 23.09.1996. 2nd ed. São Paulo: Revista dos Tribunais, 1999.

GAIO JR., Antonio Pereira. Lei n. 9.307/96: natureza, historicidade e constitucionalidade da arbitragem no Brasil. In: Arbitragem. GAIO JR., Antonio Pereira e MAGALHAES, Rodrigo Almeida. (coords). Belo Horizonte: Del Rey, 2012.

LEMES, Selma. O Superior Tribunal de Justiça e a Convenção de Nova York: Uma Nova Era para a Arbitragem e o Comércio Internacional. Avaliable at: http://www.ccbc.org.br/ingles/arbitragem. asp? subcategoria $=$ artigos\&codnoticia $=43$ Access on 24/10/2012 A Lei Brasileira de Arbitragem e a Convenção de Nova Iorque sobre Reconhecimento e Execução de Sentenças Arbitrais Estrangeiras: O Futuro Próximo . Available at: http://www.selmalemes. com.br/artigos/artigo_juri31.pdf Access on 24/10/2012

. Princípios e origens da Lei de Arbitragem.

REVISTA DO ADVOGADO - Associaçao dos Advogados de Sao Paulo, $\mathrm{n}^{\circ}$ 51, outubro/1997. Pags 32 - 35. Available at: http://www.selmalemes. com.br/artigos/artigo_juri16.pdf. Access on 24/10/2012

MAGALHÂES, José Carlos de. O Protocolo de Las Leñas ea eficácia extraterritorial das sentenças e laudos arbitrais proferidos nos países do Mercosul. Revista de Informação Legislativa Senado Federal, ano 36, n. ${ }^{\circ}$ 144, Brasília, out/dez 1999.

MATA DIZ, Jamile Bergamaschine. O sistema de solução de controvérsias no Mercosul eo Acordo de Arbitragem Comercial: instrumentos complementares ou excludentes? In: Arbitragem - 15 anos da Lei 9307/96. GAIO JR., Antonio Pereira e MAGALHAES, Rodrigo Almeida. (coords). Belo Horizonte: Del Rey, 2012.

OLIVEIRA, Henrique Silva. Considerações sobre o princípio KompetenzKompetenz na lei de arbitragem. Trigueiro Fontes Advogados, Curitiba, junho de 2005. Available at: http://www.trigueirofontes.com.br/asp/ artigos_texto.asp?Cod=79. Access: June, 2007.

PUCCI, Adriana Noemi. Arbitragem Comercial nos países do Mercosul. São Paulo: LTr, 1997.

SANTOS, Ricardo Soares Stersi dos. Mercosule Arbitragem Internacional 
Comercial: aspectos gerais e algumas possibilidades. Belo Horizonte: Del Rey, 1997.

TEIXEIRA, Sálvio de Figueiredo apud FIGUEIRA JR., Joel Dias. Arbitragem, Jurisdição e Execução: Análise crítica da Lei 9.307, de 23.09.1996. 2nd ed. São Paulo: Revista dos Tribunais, 1999.

TEIXEIRA, Sálvio de Figueiredo. A arbitragem no sistema jurídico brasileiro. Jurisprudência Mineira, v. 47, n. 137/138, p. 1-13, jul./dez. 1996. Available at: <http://bdjur.stj.gov.br/dspace/handle/2011/10240>. Access on 19/12/2012.

THEODORO JÚNIOR, Humberto. Curso de Direito Processual Civil volume I. Rio de Janeiro: Forense, 2005.

VALLADARES, Leandro Carlos P., MATA DIZ, Jamile Bergamaschine. Considerações sobre o Acordo de Arbitragem do MERCOSUL e a Lei de Arbitragem brasileira. Revista Parlatorium. FAMINAS: Belo Horizonte, v. 5, 2010.

MARTINS, Pedro Antônio Batista. Anotações sobre arbitragem no Brasil e o projeto de lei no Senado 78/92. Revista de Processo. São Paulo, vol. 77, 1995.

STRASSMANN , Karin; LUCHI, Cínthia. O instituto da arbitragem no Brasil. Available at http://tribunalarbitralbrasileiro.org/site/portfolio/oque-e-arbitragem/. Access on 24/10/2012. 